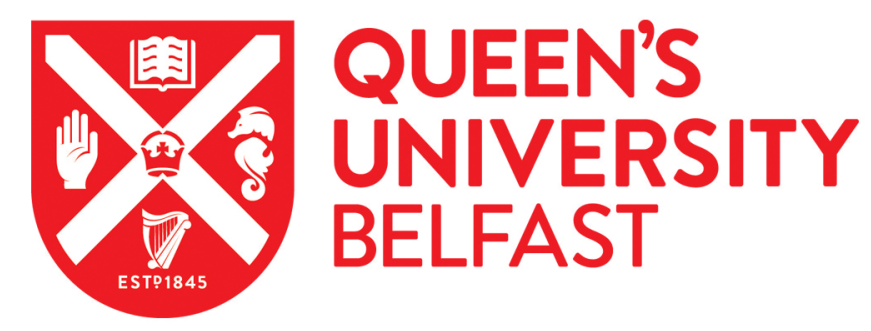

\title{
Let The People Sing? Irish Rebel Songs, Sectarianism, and Scotland's Offensive Behaviour Act
}

Millar, S. R. (2016). Let The People Sing? Irish Rebel Songs, Sectarianism, and Scotland's Offensive Behaviour Act. Popular Music, 35(3), 297-319. https://doi.org/10.1017/S0261143016000519

Published in:
Popular Music

Document Version:

Peer reviewed version

Queen's University Belfast - Research Portal:

Link to publication record in Queen's University Belfast Research Portal

Publisher rights

〔 2016 Cambridge University Press. This work is made available online in accordance with the publisher's policies.

\section{General rights}

Copyright for the publications made accessible via the Queen's University Belfast Research Portal is retained by the author(s) and / or other copyright owners and it is a condition of accessing these publications that users recognise and abide by the legal requirements associated with these rights.

Take down policy

The Research Portal is Queen's institutional repository that provides access to Queen's research output. Every effort has been made to ensure that content in the Research Portal does not infringe any person's rights, or applicable UK laws. If you discover content in the Research Portal that you believe breaches copyright or violates any law, please contact openaccess@qub.ac.uk. 


\title{
Let the people sing? Irish rebel songs, sectarianism, and Scotland's Offensive Behaviour Act ${ }^{1}$
}

\section{STEPHEN R. MILLAR}

School of History, Anthropology, Politics, and Philosophy, Queen's University Belfast, Northern Ireland BT7 1NN, UK

Email: smillar25@qub.ac.uk

\begin{abstract}
Irish rebel songs afford Scotland's Irish diaspora a means to assert, experience, and perform their alterity free from the complexities of the Irish language. Yet this benign intent can be offset by how the music is perceived by elements of Scotland's majority Protestant population. The Scottish Government's Offensive Behaviour Act (2012) has been used to prosecute those singing Irish rebel songs and there is continuing debate as to how this alleged offence should be dealt with. This article explores the social function and cultural perception of Irish rebel songs in the west coast of Scotland, examining what qualities lead to a song being perceived as 'sectarian', by focusing on song lyrics, performance context, and extra-musical discourse. The article explores the practice of lyrical 'add-ins' that inflect the meaning of key songs, and argues that the sectarianism of a song resides, at least in part, in the perception of the listener.
\end{abstract}

\footnotetext{
${ }^{1}$ This article is based on a paper that was delivered at the IASPM Biennial UK and Ireland Conference, University College Cork, on 14 September 2014. I wish to thank those who attended, Kay Goodall, and the article's two anonymous readers for their comments and suggestions.
} 


\section{Introduction}

On 1 March 2012, the Scottish Parliament enacted the Offensive Behaviour at Football and Threatening Communications (Scotland) Act making the singing of 'sectarian songs' punishable by an unlimited fine and up to five years in prison. ${ }^{2}$ Despite every other major political party voting against it, the ruling Scottish National Party (SNP) used its parliamentary majority to pass the Bill in an attempt to 'tackle sectarianism . . . particularly where it incites religious hatred' (Scottish Government 2011:1). The Government argued that new legislation was required to address the issue, pointing to a series of events in 2011 that included: the chairman of the Scottish Police Federation calling for a ban on Old Firm ${ }^{3}$ fixtures in light of the violence and trouble associated with them (Churchill 2011); a heated, public altercation by the football managers of Celtic and Rangers; liquid explosives posted to high-profile Celtic supporters (Carrell 2011); a knife posted to prominent Rangers supporter Donald Findlay QC (Watt 2011); live bullets posted to Cardinal Keith O'Brien's Edinburgh home (Hamilton 2011); and a heightening of tensions in Northern Ireland (McDonald 2011). ${ }^{4}$

The connection between football and sectarianism in Scotland is well documented, ${ }^{5}$ yet the relationship between music and sectarianism remains under researched. The Old Firm's song traditions have been strongly influenced by binarisms between Catholicism/Protestantism, Irish nationalism/British unionism, and republicanism/loyalism,

\footnotetext{
${ }^{2}$ See Scottish Government website <http://www.scotland.gov.uk/Topics/Justice/law/sectarianism-action$\underline{1 / \text { football-violence/bills. }}$.

${ }^{3}$ The 'Old Firm' is commonly used to denote Celtic and Rangers collectively.

${ }^{4}$ The Government commissioned a TNS-BMRB poll, which revealed that $89 \%$ of people agreed that sectarianism was offensive, while $91 \%$ agreed 'stronger action was needed' to tackle the problem (TNS-BMRB 2011:44-51).

${ }^{5}$ Support for Scotland's two biggest football teams is—largely-split across ethno-religious lines: 'IrishCatholic' Celtic and 'Protestant' Rangers. A 2003 survey by the NFO revealed that $74 \%$ of those who supported Celtic identified as Catholic, only $4 \%$ describing themselves as Protestant, while $65 \%$ of Rangers fans identified as Protestant, with 5\% describing themselves as Catholic (NFO 2003:10). For more on the connection between football and sectarianism in Scotland see Bradley 1995; 2004, 2006; Finn 2000; Devine 2000; Bruce et al. 2004; Rosie 2004; Kelly 2011; Waiton 2012; Flint and Kelly 2013; Hinchliffe et al. 2015; Goodall et al. 2015.
} 
yet prior to 2012 the two teams' experiences were quite different under the law. Using earlier legislation, ${ }^{6}$ Scottish courts could impose additional penalties for offences aggravated by religious prejudice; those singing songs such as 'Hullo, Hullo', 'The Famine Song', and 'No Pope of Rome', sung by some Rangers fans against arch-rivals Celtic, could be prosecuted owing to their anti-Catholic content. ${ }^{7}$ Yet, despite causing offence to some, the law was ineffective against Celtic fans' singing Irish rebel songs because it was unclear as to whether they were religious or political. ${ }^{8}$

The Offensive Behaviour at Football and Threatening Communications Act has been used to charge those singing rebel songs, ${ }^{9}$ yet there is continuing debate over how this alleged offence should be dealt with. ${ }^{10}$ Further, although singing sectarian songs in public is now illegal in Scotland, there has been no official definition as to what actually constitutes a 'sectarian song' and so it is left to the police to exercise their discretion in the matter (Waiton 2012:40-41). While some have focused on the use and interpretation of anti-Catholic music in Scotland (McFarland 1990; McKerrell 2012, 2015; Davies 2013; Millar 2015), there has

\footnotetext{
${ }^{6}$ In a previous attempt to tackle sectarianism in Scotland, the Scottish Labour-led Government introduced a new statutory aggravation under Section 74 of the Criminal Justice (Scotland) Act 2003. This enabled an existing offence to be treated as having been aggravated by religious prejudice. Despite sectarianism being a problem in Scotland for centuries, this was the first time that crimes motivated by religious intolerance were ever systematically labelled and recorded as such by the courts.

${ }^{7}$ For more on the use of 'The Famine Song' and 'Hullo, Hullo' in Scotland see McKerrell 2012 and Millar 2015.

${ }^{8}$ The convener of the Scottish Parliament's Justice Committee-SNP MSP Christine Grahame-made this point explicitly when she complained that Section 74 of the Criminal Justice (Scotland) Act 2003 'does not tackle sectarianism in terms of what Celtic fans are doing' and that arrests under that law were 'not even', with many more Rangers fans being arrested than Celtic fans (Grahame 2011:255).

${ }^{9}$ Recent Government statistics show that there were a total of 268 charges in the year following its introduction. The accused were mostly male (99\%) and under the age of $30(73.5 \%)$ with police reports indicating that $27.6 \%$ of charges involved those under the influence of alcohol. While there were charges reported in all 32 of Scotland's regional councils, $42.2 \%$ of charges took place in Glasgow. In the first 13 months following the introduction of the Act there were 87 convictions from 128 concluded charges, an overall conviction rate of 68\% (Goulding and Cavanagh 2013).

${ }^{10}$ In 2013, a sheriff acquitted twenty-year-old Dion McLeish, a Celtic supporter, who had been charged with singing rebel songs at a football match in Dundee. In a controversial move for an impartial public official, the judge blamed Scotland's sectarian problems on denominational schools, described the new law as 'horribly drafted' and stated: 'If they can proscribe a list of songs which people are banned from singing, they will find the courts are full and the football grounds are empty' (Cochrane 2013).
} 
been little academic analysis of the use of Irish rebel songs (Boyle 2002), which some consider to be anti-Protestant. ${ }^{11}$ This article explores the social function and cultural perception of Irish rebel songs in the west coast of Scotland, examining what qualities lead to a song being perceived as 'sectarian', by focusing on song lyrics, performance context, and extra-musical discourse. The article explores the practice of lyrical 'add-ins' that inflect the meaning of key songs and argues that the sectarianism of a song resides, at least in part, in the perception of the listener.

\section{Sectarianism in Scotland}

Sectarianism in Scotland can be traced back to the Reformation, when the country adopted a stricter and more puritanical Protestantism than that of England. While the Anglican Church of England considered itself both Catholic and Reformed, the Presbyterian Church of Scotland found the two mutually exclusive. Presbyterianism became a key part of Scotland's identity and something that, for three hundred years, 'defined the Scots to one another and to the rest of the world' (Gallagher 1991:34). When the country formed a political union with England, in 1707, the sovereignty of the Church of Scotland was non-negotiable, its serving to retain Scotland's identity within a larger polity. Yet such connections proved difficult for non-Protestants. James Handley refers to Scotland as having 'traditional anti-Catholic prejudices' and the country's Catholic population were the victims of sectarian prejudice and sporadic sectarian attacks throughout the eighteenth century (Handley 1945: 288-289).

In the nineteenth century, the Industrial Revolution created tensions between Scotland's population as a large influx of unskilled Irish labourers 'undertook the type of work the native Scots would not or could not perform' (Marshall 1996:1). The incoming Irish sought better wages and upward social mobility, gaining employment in the manufacturing,

\footnotetext{
${ }^{11}$ Although there is crossover between the two, the focus of this article is on Irish rebel songs, which form part of a long musical tradition, as opposed to ad hoc football chants devised by fans (Skeide 2010:83-84).
} 
mining and transportation industries. Irish immigration was such that by 1840 , working-class Irishmen were a prominent minority in Glasgow (Evans 2001:383), while Scotland, as a whole, had a 'substantially larger proportion of Irish immigrants than either England or Wales' (Ibid., 455). The vast majority of such immigrants were Catholic and thus doubly disadvantaged, being both a national and religious minority. ${ }^{12}$ Such differences were readily apparent through their accents and 'Irish' and 'Catholic' were conflated and subordinated to form a new Constitutive Other. With the mass failure of Ireland's potato crop in 1845, the steady stream of Irish workers into Scotland quickly became a torrent, as huge numbers fled the devastating effects of the Great Famine (Adamson, 1994:20). Many of those who arrived in Scotland were poor and desperate, compounding the negative stereotypes already surrounding the Irish in Scotland (Handley 1945:170-171). As the century drew on, the Church of Scotland offered aid and sustenance to Scotland's new Irish community, yet such assistance was often conditional upon the recipient renouncing their Catholic faith (Burke 2004:103).

Seeking to alleviate the socioeconomic situation of Glasgow's large Irish-Catholic community, Brother Walfrid, a Glasgow-based Irish-Catholic monk, formed Celtic Football Club as a charitable organisation in November 1887, using Celtic as a means to raise funds to feed and clothe the poor in the city's East End. Given Celtic's Irish connections, Irish nationalism and Home Rule politics were prevalent from the club's inception and Michael Davitt, founder of the nationalist Irish Land League, was invited to lay the first piece of turf at Celtic Park, which was transported from County Donegal (Gallagher 1987:26). ${ }^{13}$ The team played their first match against Rangers Football Club, another Glasgow-based team that had

\footnotetext{
${ }^{12}$ Roughly one fifth of Irish immigrants were Protestant and did not suffer the same fate as their Catholic countrymen. These Ulster Protestants were easily assimilated into Scottish society and shared common cause with those opposed to the Catholic Irish (Gallagher, 1991:20).

${ }^{13}$ This ritual was repeated a century later, when members of a Donegal Celtic Supporters Club cut a square yard of grass, which was blessed by a priest and transported to Scotland, before being laid in the centre circle of the refurbished Celtic Park in 1995 (Boyle 1995).
} 
been formed some sixteen years earlier. Rangers had a strong Protestant, British unionist identity, which emerged in the late nineteenth century, with their connection to the Clyde shipyards, and intensified when the Belfast-based Harland and Wolfe established a Glasgow base in 1912. Such factors contributed towards Rangers' policy of refusing to sign Catholic players, which began in the $1920 \mathrm{~s},{ }^{14}$ and formed part of a general climate of anti-Catholicism that stretched throughout the decade and beyond. In 1920, Alexander Ratcliffe formed the right-wing, anti-Catholic, Scottish Protestant League and in 1923 the Church of Scotland published its infamous sectarian tract 'The Menace of the Irish Race to our Scottish Nationality', which accused Irish Catholics of subverting Scotland's Presbyterian values through drunkenness, crime, and fecklessness (Bruce et al. 2004:128). ${ }^{15}$ The Global Depression heightened sectarian tensions, as Irish Catholic immigrants became convenient scapegoats to explain the country's economic downturn. In 1933, Ratcliffe's Scottish Protestant League gained over 71,000 votes in Glasgow, some $23 \%$ of the total, before infighting and dissatisfaction saw the party fade into obscurity (Smyth 2000:196).

Tensions between Scotland's Catholic and Protestant population increased, again, with the onset of the Troubles, a thirty-year ethno-national conflict in Northern Ireland that began as a Civil Rights movement to attain equal treatment for Catholics under the law, but became a struggle over Northern Ireland's constitutional position within the United Kingdom. Scottish soldiers were sent to keep the peace, yet their perceived Protestant unionist bias complicated their task (Wood 1994:154). The close cultural ties between the Protestant unionist community and the Scottish soldiers compounded Catholic nationalist suspicions

\footnotetext{
${ }^{14}$ Rangers' no-Catholic signing policy ended in 1987 (Bruce et al. 2004:128-129).

${ }^{15}$ During this period the Irish in Scotland maintained an important link with their homeland. Gallagher writes that by 1921 'almost every Scottish town with a sizable Irish presence had its own IRA company that was required to send a regular quota of revolvers, ammunition, and rifles to headquarters in Glasgow' (Gallagher 1987:91).
} 
over the soldiers' neutrality. ${ }^{16}$ Wood quotes one Belfast resident who recounted hearing Scots soldiers singing loyalist songs 'at the tops of their voices' while driving through exclusively Catholic nationalist areas remarking: 'They were making an essential point for the IRA more effectively than the IRA could do themselves' (Ibid., 152). Such singing was commonplace in Scotland's football terraces and there were many songs influenced by the Troubles sung by both Rangers and Celtic supporters. The connection between Rangers supporters' songs and sectarianism has been examined elsewhere ${ }^{17}$ it is to songs sung by Celtic supporters to which we now turn.

\section{What is Irish rebel music?}

Irish rebel music is a subgenre of Irish folk music, with much the same instrumentation, but with lyrics predominantly concerned with Irish republicanism. Rebel music has a long history, which largely stems from-and focuses on - the country's awkward and complicated relationship with its larger island neighbour: Great Britain. Irish rebel songs draw on many themes including colonialism, discrimination, racism, republicanism, slavery and sedition. Historically, those singing them have risked being hanged (Curtis, 1985), flogged (Warfield, 2006), or imprisoned (Waiton, 2012), suggesting a longstanding awareness of their political power. Many rebel songs are centuries old and, like many folksong traditions, are preserved and distributed through oral transmission. As with Stephanus Muller's work on Nkosi, the pan-African liberation anthem, rebel songs' 'humble and rather obscure origins and the lack of information available about the composer[s], conspire to invest [them] with the elusive kudos accompanying the words "by the people" (Muller 2001:24). Yet just as there is no

\footnotetext{
${ }^{16}$ In addition to their support for Celtic and Rangers, loyalist and republican flute bands, in Scotland and Northern Ireland, regularly cross the Irish Sea to take part in each others parades, renewing cultural and familial bonds between the two territories. However, the relationship between loyalist and republican bands in Scotland and Northern Ireland is beyond the scope of this article.

${ }^{17}$ See McKerrell 2012, 2015; Davies 2013; and Millar 2015.
} 
official definition as to what constitutes a 'sectarian song', neither is there an authoritative definition of 'Irish rebel music'; it has no place in The New Grove Dictionary of Music and Musicians or the Oxford Dictionary of Music, a testament to its underground, underresearched, and under-valued nature within the academy.

Although there have been many prominent Protestant Irish republicans, particularly among the late eighteenth-century United Irishmen, rebel music has become polarised over religious grounds and it is now strongly associated with the Catholic community; it is pejoratively referred to as 'diddly-dee' music (Stokes, 1994; Cooper, 2010). While very few rebel songs are overtly anti-Protestant, ${ }^{18}$ in the way that their loyalist equivalents are antiCatholic, some argue they are 'politically sectarian' due to the way they are used against the loyalist and unionist communities of Scotland and Northern Ireland and their anti-British stance more generally (Gow, 2013). That these songs are sung almost exclusively by the Catholic community further exacerbates their perception as sectarian.

Bradley makes reference to an Irish rebel scene in Scotland 'where mainly young men (but not solely) gather in venues where bands perform songs that remember and celebrate perceived patriots and "freedom advancing” events in Irish history' (Bradley et al., 2009:195). He describes this as 'a qualitatively different version of the Irish-British colonial conflict from that which dominates throughout much of Britain, particularly in much of the British media' (Ibid.). Within a football setting, Bradley describes how Celtic supporters use such songs and the appeal they have for fans and members of the Irish diaspora. He quotes one fan who said:

[A]ll these guys had the same views, sang the same songs and just thought the same as me. I mean I could be totally wrong, but standing there in that crowd, that was the feeling I got and it was the only time in the whole week I could get that feeling . . .

\footnotetext{
${ }^{18}$ The most obvious exception to this is 'Roamin' In The Gloamin'. However, this song will be discussed, in detail, later in the article.
} 
every week you could stand there to your heart's content and it made me feel really Irish, it made me feel really good (Bradley, 2006:1195).

Such environments offer Scotland's Irish diaspora an opportunity to express and perform a particular form of Irish republicanism in spite of their geographical remoteness from the island. Anderson points to such instances of group singing as 'occasions for unisonality, for the echoed physical realization of the imagined community' (Anderson, 1991:145), highlighting the important role music plays in creating collective identities and consolidating group cohesion. Through their vivid depiction of Self and Other, rebel songs also chime with Frith's theorisations of identity as 'an experiential process which is most vividly grasped as music [emphasis in original]' owing to the intensity with which it offers 'a sense of both self and others, of the subjective in the collective' (Frith, 1996:110).

The use of such songs also resonates with Stokes' explanation of Celtic music's appeal to the Irish diaspora, where "Celtic" music . . . allows people access to - in their own terms - a domain of "Celtdom" denied to them by the complexities of, for example, a Celtic language, or the theoretical and practical difficulties of maintaining a coherent political identity' (Stokes, 1994:6). Boyle posits that the commemorative nature of Scotland's rebel music scene, which has grown exponentially since the 1990s, is a direct consequence of the mass-assimilation of the country's Irish community and is tied to 'a deepening crisis of identity along not just one, but a multiplicity of axes (age, gender, class and so on, as well as nationality)', which have created the need for a 'redemptive identity' (Boyle 2002:183). Boyle posits that the rebel music scene, functioning in different ways for different groups, has grown in popularity because of its promise to provide such an identity and conceives of it 'as an effort to "crystallise and secrete" models of masculinity which restore a sense of 
ontological security to young adult males uncertain about their place or role in society' (Ibid., 184).

Thus, in their most positive sense, Irish rebel songs afford Scotland's Irish diaspora a means to assert, experience, and perform their Irish-Catholic alterity collectively. Yet this benign intent can be offset by how the music is perceived by elements of Scotland's majority Protestant population. The Wolfe Tones are an example of Celtic music - in both senses of the word-and those at their concerts, in football terraces, and in pubs across the country clearly deploy this music as a signifier of their Irish identity, free from the complexities of the Irish language. Yet their music is not universal.

\section{The Wolfe Tones}

The Wolfe Tones are perhaps the most well-known example of an Irish rebel band, having performed over 14,000 shows throughout the past fifty years, in such venues as New York's Carnegie Hall, the Paris Olympia and Melbourne's Victoria Hall (Warfield 2006:185). The band's accolades include being awarded the keys to the cities of New York and Los Angeles, while their version of Thomas Davis' nineteenth-century rebel song 'A Nation Once Again' was voted the world's favourite song in a 2002 BBC World poll (Warfield 2012). The quartet formed in Kilrush, County Clare, in August 1963, recorded several albums and had twelve top-ten hits in the Irish charts. ${ }^{19}$ The band's name derives from the leader of the 1798 Irish Rebellion, Theobald Wolfe Tone, and much of their music espouses their republican politics. The Wolfe Tones toured regularly and enjoyed support from across the English-speaking world. Yet when Derek Warfield dissolved the group, in 2001, Fintan O'Toole of The Irish

\footnotetext{
19 'Wolfe Tones', Encyclopedia of Popular Music, fourth edition, edited by Colin Larkin, Oxford Music Online, Oxford University Press, accessed 12 August 2014. $<$ http://www.oxfordmusiconline.com/subscriber/article/epm/30775>
} 
Times described it as: 'A win-win situation. A gain both for Irish traditional music and for Irish politics' (O'Toole 2002). O'Toole described the group as 'one of the key weapons in the republican armoury' and said their music expressed 'a visceral hatred of all things English' (Ibid.).

The Wolfe Tones' career pre-dates Northern Ireland's Troubles and the band continued to perform after the Good Friday Agreement, yet their music and its message are frequently associated with the Provisional IRA and its campaign. Following the band's split, three of the four founding members quickly reformed as 'Brian Warfield, Tommy Byrne and Noel Nagle formerly of The Wolfe Tones'. They continue to enjoy some popularity, particularly in Scotland, Ireland and North America, performing their unique brand of rebel songs across the English-speaking world. Yet their music remains contentious and highly divisive. Large portions of the Wolfe Tones' followers are drawn from Celtic football fans and the band's members are staunch supporters of the team. ${ }^{20}$ It is telling that Bruce begins his description of Celtic Football Club with reference to its song tradition (Bruce et al. 2004:128-129). The Wolfe Tones wrote and recorded 'Celtic Symphony' in 1988 to celebrate Celtic's centenary and the music video was filmed inside Celtic Park, illustrating the close relationship they once enjoyed with the club's owners.

\section{Chorus of 'Celtic Symphony, 21}

Graffiti on the walls just as the sun was going down,

I seen graffiti on the walls (of the Celts, of the Celts)

Graffiti on the walls that says we're magic, we're magic

Graffiti on the walls, graffiti on the walls. And it said:

'Ooh ah up the Ra, say ooh ah up the RA' (x6)

\footnotetext{
${ }^{20}$ In a chapter on the rebel music scene in 1990s Scotland, Boyle writes that 'no statistical profile has been, or probably could have been, obtained through primary research' owing to its 'subversive' nature (Boyle 2002:184-188). Two decades on, audiences' suspicions have been compounded by the Scottish Government's new law, rendering the collection of such statistics yet more difficult. Nevertheless, through participant observation, interviews with those in the scene, and the Celtic-themed songs written by the band, I can say with certainty that there is a strong affiliation between Celtic football supporters and the Wolfe Tones.

${ }^{21}$ Lyrics transcribed from the Wolfe Tones' 2006 compilation album Celtic Symphony.
} 
'Celtic Symphony' is one of the most popular - and controversial—rebel songs sung in Scotland today, yet while thousands used to sing this at Celtic Park, it is not often heard in full anymore, largely because of the Government's new law. When it is heard, the offending chorus 'Ooh Ah, Up The RA', the 'RA' being the IRA, is often substituted for or 'Ooh, Ah, Up The Celts' or 'Ooh Ah, Samaras'. 22

Another rebel song popular amongst Celtic supporters, and popularised by the Wolfe Tones, is Paddy McGuigan's 1968 'Boys Of The Old Brigade', a song about the role of the IRA during the Irish War of Independence (1919-1921). The lyrics to the first verse and chorus are given below; the 'add-in' is included in parenthesis:

\section{Excerpt from 'Boys Of The Old Brigade' 23 \\ Oh son, I see in memory true, \\ Of far of distant days, When, being just a lad like you, I joined the IRA (PROVISIONAL WING!)}

While there used to be a close relationship between the Wolfe Tones and Celtic Football Club, Celtic's board have moved to distance themselves from the Wolfe Tones-and Irish republicanism more generally - due to rebel music's perceived sectarian nature. This was illustrated on 18 December 2002, when Celtic's chief executive wrote to the club's 50,000 season ticket holders asking them to stop singing pro-IRA songs (Kelly 2003:43). Under the Scottish Government's new law, several of the Wolfe Tones' songs have effectively been outlawed and Celtic no longer allow the band to advertise their shows in its programmes $\left(\right.$ Kenny 2002). ${ }^{24}$

\footnotetext{
${ }^{22}$ Georgios Samaras is the name of a former Celtic player.

${ }^{23}$ Lyrics transcribed from the Wolfe Tones' 1974 album 'Till Ireland A Nation.

${ }^{24}$ The Scottish Government 'refused to spell out which songs sung by fans would be illegal under the bill' leaving this to 'the discretion of the police' (Waiton 2012:40). However Scotland's Lord Advocate, Frank
} 
Scotland's preeminent historian, T.M. Devine, argued that singing pro-IRA songs was not sectarian because the IRA was not sectarian in intent. ${ }^{25}$ Yet, while true on one level, his comments ring hollow to many because of the IRA's perceived sectarian nature, particularly that of the Provisional IRA (PIRA) and other, more recent, dissident groups such as the Continuity IRA (CIRA), the Real IRA (RIRA), and the 'new IRA'. ${ }^{26}$ For those within Northern Ireland's Protestant community, 'IRA violence against so-called "legitimate" targets of the State has been experienced ... as ethnic cleansing' (Higgins and Brewer 2003:109). Higgins and Brewer maintain this is as a result of the interconnection between Protestant identity and British identity and that 'anti-Britishness easily blends into antiProtestantism as Protestants perceive it' (Ibid.). Of the 1064 Protestants killed during Northern Ireland's 'Troubles', three quarters were killed by the PIRA (Fay, Morrissey and Smyth 1998). The PIRA purported to be the protector of Northern Ireland's Catholic community and so are often viewed as a manifestation of that community; that the majority of Protestants - many of whom maintain close cultural, historical, and familial links with Scotland-were murdered by the PIRA problematises any attempt to classify the PIRA as non-sectarian. That the PIRA were, and are, often simply referred to as 'the IRA' further complicates this issue.

\section{Reception conditions meaning}

In keeping with the Barthesian notion that meaning is created by the recipient (Barthes 1977),

Mulholland, issued police with a ten-page guideline outlawing 'The Boys of The Old Brigade' and the 'Celtic Symphony' chant 'Ooh Ah, Up The Ra' under the Offensive Behaviour at Football and Threatening Communications (Scotland) Act (Rose 2012).

${ }^{25}$ No Byline. 'Sheriff right to dismiss case against man singing IRA songs, says expert' The Scotsman, 30 March 2011.

${ }^{26}$ The latter group is a merger of the RIRA, the Derry-based Republican Action Against Drugs (RAAD), and other non-aligned republicans; it was responsible for murdering a Protestant prison officer, David Black, who was also a member of the Orange Order, in County Armagh on 1 November 2012 (BBC 2012). 
Dahlhaus offers an explanation as to how such a process functions within music. Writing about perception in relation to 'nationalistic music', he argues:

[I]f a composer intended a piece of music to be national in character and the hearers believe it to be so, that is something which the historian must accept as an aesthetic fact, even if stylistic analysis - the attempt to 'verify' the aesthetic premise by reference to musical features - fails to produce any evidence. There is no line of argument which would make it permissible to leave ideological 'appearances' out of account in assessing the aesthetic 'reality' (Dahlhaus 1980:86-87).

For many in Scotland, particularly those of a Protestant, unionist, or loyalist persuasion, the ideological appearance of rebel songs is that they are sectarian. Despite some claiming they are singing 'political songs', they become sectarian on account of their being perceived that way. ${ }^{27}$ Indeed Dahlhaus extends this premise to the realm of folk music, in the second section of his chapter, where he uses the example of 'gypsy' music as authentic Hungarian music:

[S]o long as gypsy music in Hungary was regarded as authentically Hungarian, it was authentically Hungarian; the historical error has to be taken at its face value as an aesthetic truth, for it takes a collective agreement to stamp certain traits as national ones (Ibid., 92).

That some in Scotland hear 'Celtic Symphony' and 'The Boys of the Old Brigade' as sectarian means we must treat their historical error as an aesthetic truth. It is often argued that these rebel songs refer not to the recent Troubles, but, rather, to the early twentieth century and the formation of the Irish Free State. Yet the inclusion of the add-in 'Provisional Wing' to 'The Boys of the Old Brigade' transforms the song's meaning, relocating it within another, much more contentious, socio-political context.

A similar argument could be made with the Wolfe Tones' ballad 'Joe McDonnell'.

\footnotetext{
${ }^{27}$ Similar arguments are often made of Wagner's music, with some listeners unable to divorce the composer's anti-Semitism from his music. One advocate of this line of thought is Richard Taruskin, who maintains that 'music does not now exist, nor has it ever existed, in a social vacuum. Its meanings are not self-contained' (Taruskin 2010:22).
} 
McDonnell was arrested and interned under Section 12 of the Northern Ireland Special Powers Act for behaving 'in a manner prejudicial to the preservation of the peace or maintenance of order' (Taylor 1997:92). The Act, introduced in 1971, was a response to the 300 explosions, 320 shootings, and over 600 people hospitalised that year in Northern Ireland; it saw the mass arrest and internment-without trial—of over 300 republican suspects (Ibid. 92-93). After his release, McDonnell joined the Provisional IRA's Belfast Brigade before being arrested and imprisoned for fourteen years, following the bombing of a furniture showroom (Ibid. 243). In 1981, Joe McDonnell joined nine other volunteers who began a hunger strike over the removal of republican prisoners' Special Category Status and reclassification as criminals. ${ }^{28}$ McDonnell died on 8 July 1981, 61 days after beginning his hunger strike (Taylor 1997:247).

During the concerts I attended at Glasgow's Barrowlands, from 2012 to 2015, the Wolfe Tones' renditions of 'Joe McDonnell' were shown a reverence akin to a religious rite. ${ }^{29}$ As a mark of respect, the band asked the crowd to sit in silence, while the more pious made their way to the front to kneel at the stage. That these audiences were mostly-if only nominally - Catholic bestows the ritual with even more religious significance and serves to conflate Catholicism's connection with Irish republicanism. The various add-ins attached to 'Joe McDonnell' recontextualise its meaning, making the song much more sectarian in nature. Further, given the widespread knowledge of such add-ins, it could be argued that the meaning of each of these songs has been changed and cannot be undone, even if one omits the

\footnotetext{
${ }^{28}$ In July 1972, following an IRA-led hunger strike that lasted thirty-five days, those convicted of Troublesrelated offenses were given Special Category Status and treated as Prisoners Of War under the Geneva Convention. This meant that they did not have to do prison work, could wear their own clothes, reside with members of their own political factions, and were permitted extra visits and food parcels. However this policy ended on 1 March 1976 and those arrested after this date were classed as criminals. This prompted the 'Blanket Protest' in September 1976, the 'Dirty Protest' in April 1978, and hunger strikes in October 1980 and January 1981 (McEvoy, 2001:216).

${ }^{29}$ In a 2011 documentary, the Wolfe Tones' Tommy Byrne described Glasgow's Barrowlands as his favourite gig, while the band's Noel Nagel agreed, adding: 'They're so enthusiastic. They're so much into the show and so much into what we do and it's just electric' (Kenneally 2011).
} 
offending add-ins. ${ }^{30}$

\section{Excerpt from 'Joe McDonnell'}

And you dare to call me a terrorist

While you look down your gun (YA FILTHY HUN!)

When I think of all the deeds that you have done.

In 'Joe McDonnell', the offending add-ins are 'Ya Filthy Hun' and the long, drawn-out chants of 'P-I, P-I, P-IRA' at the end of the song. While the term PIRA is shorthand for the 'Provisional Irish Republican Army', and the audience's chanting indicates their support for the organisation, 'Hun' is something of a contested concept. Some argue a 'Hun' merely refers to a supporter of Glasgow Rangers Football Club; others consider the term to be a sectarian slight.

\section{What is a 'Hun'?}

During the Justice Committee debate over the introduction of the Offensive Behaviour at Football and Threatening Communications Bill, Jeanette Findlay-an Economics lecturer at the University of Glasgow, chair of the Celtic Trust, ${ }^{32}$ and a vocal supporter of Celtic fans' right to sing Irish rebel songs - was asked by committee member and MSP Humza Yousaf what the term 'Hun' meant, questioning whether it was sectarian. Findlay replied: 'in all my

\footnotetext{
${ }^{30}$ Controversies surrounding the ballad of 'Joe McDonnell' extend beyond Scotland and the song has proven divisive in the Republic of Ireland. In November 2014, John Delaney, Chief Executive of the Football Association of Ireland, was filmed singing 'Joe McDonnell' in a Dublin bar following Ireland's 4-1 victory over the USA. When the event became public knowledge, critics focused on the song's controversial subject matter and Delaney was lambasted in the Irish press for acting in an unprofessional manner. Delaney initially denied singing the song, threatening the Guardian newspaper with legal action if they published his details, before admitting that he sang the song, but did not support violence. The Wolfe Tones' Brian Warfield used the incident to defend the singing of rebel songs in Ireland and encouraged fans to download the song in a bid to make 'Joe McDonnell' a Christmas Number One (Early, 2014).

${ }^{31}$ Lyrics transcribed from the Wolfe Tones' 1983 album A Sense of Freedom.

${ }^{32}$ The Celtic Trust is an organisation of supporters and small shareholders that unites fans to have a greater say in the running of the club.
} 
life the term Hun has never been used to apply to a Protestant or any member of any religious group. It refers to a Rangers supporter' (Findlay 2011:170). Yousaf, himself a Celtic supporter, made reference to his hearing the term denote a supporter of Heart of Midlothian Football Club, to which Findlay replied: 'It is just applied as a football rivalry term. It doesn't have any religious connotation whatsoever; it never has' (Ibid.). The term 'Hun' is most often applied to Rangers supporters, yet Yousaf's ability to disprove Findlay's claim that it was exclusive to supporters of that club is telling. That the term is used to describe other groups such as the Orange Order and the British Army, other football teams such as Hearts, Kilmarnock and Motherwell, as well as its use within 'Joe McDonnell', suggest that there is more to the term than Findlay attests.

Nil By Mouth, Scotland's leading anti-sectarianism charity, considers 'Hun' to be 'Offensive sectarian language ... used negatively against Protestants or those perceived to be' (Scott 2013). ${ }^{33}$ The term 'Hun' is most commonly deployed against Rangers football fans where it is closely bound to the perception of their being the Protestant embodiment of the Scottish/British state. This is in contrast to the Celtic fan, the embodiment of 'the ScottishIrish-Catholic community as low other' (McKerrell 2012:2). Thus, in 'Joe McDonnell' it seems unlikely that the soldier looking down his gun is being a 'Filthy Hun' because he supports Rangers Football Club, but, rather, because he is a representative of the hegemonic power of the repressive British state, in contrast to the relatively powerless Irish-Catholic low Other.

References to 'Huns' are found in other Wolfe Tones songs. The earliest example is taken from 'The Foggy Dew', which, while not written by the band, was the title-track of their debut album in 1965 and was recorded again for their 1978 compilation Best of the

\footnotetext{
${ }^{33}$ Scott, Dave. 'Renewed call for Bigotry Rehab Scheme', Nil By Mouth, 2013, accessed 12 August 2014 $<$ http://nilbymouth.org/2013/campaigners-renew- call-for-bigotry-rehab-scheme/>.
} 
Celts; it is a popular feature in the band's set:

\section{Excerpt from 'The Foggy Dew, 34}

And from the plains of Royal Meath

Strong men came hurrying through

While Britannia's Huns, with their great big guns,

Sailed in through the Foggy Dew.

Another reference to 'Huns' appears in the form of an add-in, sung by the audience, to 'The Merry Ploughboy'. Taken from the Wolfe Tones' 1967 EP The Teddy Bear's Head, ${ }^{35}$ the song was written by one of twentieth-century Ireland's most influential songwriters, Dominic Behan, ${ }^{36}$ and has been performed by many artists; it has featured in every Wolfe Tones concert I have attended. The add-ins are, again, included in parenthesis:

\section{Excerpt from 'The Merry Ploughboy' \\ And we're all off to Dublin in the green (FUCK THE QUEEN) \\ Where the helmets glisten in the sun (FUCK THE HUNS) \\ Where the bayonets flash and the rifles crash, \\ To the echo of a Thompson gun.}

An alternative version of the song, sung by some fans, substitutes the lines 'Where the bayonets flash and the rifles crash, To the echo of a Thompson gun' for the more sectarian 'Where our bayonets slash the Orange sash to the echo of a Thompson gun'. The Orange sash is the most readily identifiable signifier of the Orange Order, an exclusively Protestant fraternal organisation that dates back to 1795 . That those singing the song wish to cut through this sash, worn across the Orangeman's torso, illustrates the willingness of some audience members to perform sectarian violence-symbolically-even if such acts are not realised

\footnotetext{
${ }^{34}$ Lyrics transcribed from the Wolfe Tones' 1965 album The Foggy Dew.

${ }^{35}$ This refers to the island of Ireland's supposed shape as a teddy bear- the north being its head.

${ }^{36}$ Behan's father fought for the IRA in the Irish War of Independence (1919-21) and his maternal uncle, Peadar Kearney, wrote the Irish national anthem. He was a member of Fianna Eireann, the youth wing of the IRA, before spending much of his life in Scotland.
} 
physically.

Lastly, and most difficult to refute, is the K.A.H. graffiti, found on walls in Northern Ireland. In a 2011 Vice documentary on Northern Ireland, the interviewer asked a Catholic teenager what it meant:

Catholic Teenager: That's 'Kill All Huns'. Protestants basically.

Interviewer: And Huns are Protestants?

Catholic Teenager: Yes (Moynihan 2011).

While it can be folly to draw too many parallels with Northern Ireland, a large portion of Celtic's support is from there, and a large part of Scotland's sectarianism stems from there. The teenager's bald conflation of 'Hun' and 'Protestant' clearly contradicts Findlay's claims.

Combined with the reference in 'Joe McDonnell', these ciphers imply the term 'Hun' does not simply refer to a Rangers football supporter. This lends weight to the suggestion that 'Hun' is a sectarian term closely bound to a British/Protestant identity. The term is fiercely defended by those who seek to deploy it in reference to Rangers supporters, but, to others, it has become a form of codified sectarianism tied to complex notions of Britishness, Protestantism and the Scottish football team seen to encapsulate these traits in their most complete form: Rangers. The notion that the Wolfe Tones' music has come to mean something greater than the sum of its parts has gained credibility among Scotland's political elite. That Scotland's Lord Advocate specifically named the chorus of the 'Celtic Symphony' and 'The Boys of The Old Brigade' as punishable under the new Act, in his guidelines to the police, emphasises how seriously the Scottish establishment takes the singing of these songs (Rose 2012).

The Wolfe Tones' Brian Warfield criticised the new law and Celtic Football Club's attempts to limit the singing of their songs in an open letter to the club, accusing Celtic's 
board of 'attacking the song traditions of Ireland' (Warfield 2011). Warfield wrote:

[B]anning or outlawing a song is morally wrong and really is just a cosmetic exercise to pacify bigots. It ignores the real problem, which lies at the heart of the society that feels a need of this oppressive action, sectarianism and racial discrimination are the main problem. Ask any Catholic who has sought a house or position of employment over the years and he will tell you about discrimination. It is nothing to do with music or song, which is just a reaction to the problem.

... Get rid of sectarianism and injustice in the society and the song is just a song it's a harmless story. WHAT ARE THE REASONS WE REQUIRE TO BAN A SONG, DOES IT JUST HAVE TO BE IRISH. WILL WE GO AS FAR AS BANNING THE FLOWER OF SCOTLAND OR SONGS ABOUT BONNIE PRINCE CHARLIE or the JACOBITES ARE THEY REBEL SONGS [emphasis in original]. I think not, try it and you will meet with opposition (Ibid.).

Warfield continued by linking the rebel songs sung by Celtic football fans to 'seditious music' of the past:

The policy you have now embarked upon is unjust and oppressive and if you study history it was counter productive in the past. There is a history of outlawing and banning songs and songsters against the Irish and the Scots. Yet there is more so called seditious music surviving from these traditions than from any other country in Europe. Many harpers and bards were beheaded, many minstrels were exiled or imprisoned for carrying the story of their people. STILL THEIR MUSIC LIVES ON TO THIS DAY [emphasis in original] . . . Why is it that the Irish song tradition is attacked as a problem, they are not sectarian or bigoted in words or expression but carry the story of the Irish peoples' struggle against oppression, hunger and injustice. It's the story of human misery and suffering, of a fight against famine and disease, and then a fight for freedom and human dignity (Ibid.).

In response to the Scottish Government and the board of Celtic Football Club's 'attacking the song traditions of Ireland', the Wolfe Tones released 'The Celtic People', found on their latest album Child of Destiny, which strikes a defiant tone towards the new law.

Excerpt from 'The Celtic People ${ }^{, 37}$

I'm proud to be a Celtic supporter,

We don't sing sectarian songs.

We sing the songs of Ireland's freedom,

Sing the songs of our native land.

${ }^{37}$ Lyrics transcribed from the Wolfe Tones 2012 album Child of Destiny. 
At a concert I attended in Glasgow's Barrowlands, on 24 November 2012, Brian Warfield prefaced the song with a long and drawn-out attack on Scotland's lawmakers and their enforcers - the police. There was a heavy police presence at the concert, more than I have seen at any of their gigs or any concert in that venue. Warfield implored the crowd to stand with him in rejecting the new law and shouted at the police:

This music is not sectarian - so get it into your head!

We are not sectarian!

The people of Glasgow are not sectarian! [Audience cheers]

Are you listening Strathclyde police!?

They tried to criminalise Irish music hundreds of years ago and they're trying to do it again. $^{38}$

Yet Warfield is not alone in his rejection of the new law. As mentioned, none of the other main political parties voted to pass the new legislation and were it not for the SNP's large parliamentary majority, it would not have succeeded in becoming law. During Scotland's 2012 council elections, several months after the Act became law, one independent candidate in Glasgow based his entire campaign around opposing the law. ${ }^{39}$ The candidate, Thomas Rannachan, believed the new law to be a disproportionate response to a long-standing issue and argued it was a 'Trojan horse' in vilifying the Irish-Scottish community and also the young unemployed male community, which he believed would be 'hardest kicked by this beast'. ${ }^{40}$ Rannachan's disapproval of the law is perhaps understandable with regards the

\footnotetext{
${ }^{38}$ Taken from the Wolfe Tones' concert at the Barrowlands, Glasgow, 24 November 2012 and transcribed by the author.

${ }^{39}$ Although the candidate was unsuccessful in the election, he claimed to have received support from all over Scotland and stated that if it had been concentrated enough within his Glasgow Ward he would have easily won the seat. As a result, he has indicated he may stand for election at the national level in 2015, on the same platform.
} 
nuanced performance of some rebel songs, which require add-ins to become sectarian. Others are more difficult to defend.

\section{Roamin' in the Gloamin'}

As with much music in the sectarian canon, 'Roamin' in the Gloamin', is recycled, or, in musicological terms, contrafactum. Both the tune and title are borrowed from a 1910 song that was written, composed, and sung by the Scottish entertainer Harry Lauder. First performed during the Christmas pantomime Red Riding Hood, in Glasgow's Theatre Royal, the song was an instant success and proved to be Lauder's biggest hit (Irving, 1968:58-59).

\section{Chorus of Roamin' in the Gloamin',41}

Roamin' in the gloamin' on the bonnie banks o' Clyde.

Roamin' in the gloamin' wi' ma lassie by ma side.

When the sun has gone to rest, that's the time I like the best, $\mathrm{O}$, it's lovely roamin' in the gloamin'!

That Lauder's old-time Scottish song has been reworked as an Irish rebel song is deeply ironic, particularly when one considers his background.

A short, sturdy man bedecked in kilt and balmoral, Lauder was the archetypal 'Scotsman' and his persona 'did more than any other person to propagate the image of the Scot' (Irving, 1968:8). Lauder's family was devoutly Protestant, following the Calvinist tradition of Scotland's national church, a tradition he himself maintained (Lauder, 1928:3132). Lauder made his professional debut in the loyalist town of Larkhall, before achieving a success that saw him perform his unique blend of music and comedy throughout the English-

\footnotetext{
${ }^{40}$ Rannachan, Thomas. 'No to year zero and no to the Offensive Behaviour at Football Act', Tumblr, 7 April 2012, accessed 14 August 2014 <http://thomasrannachan.tumblr.com/post/20675646515/no-to-year-zero-andno-to-the-offensive-behaviour-at $>$.

${ }^{41}$ Lyrics transcribed from Harry Lauder's 2008 album Roamin' In The Gloamin'.
} 
speaking world (Irving, 1968:28). Harry Lauder's son was killed while serving in the First World War and, after volunteering and being turned down on account of his advanced years, Lauder pressed the War Office to allow him to travel to France and entertain the troops, in memory of his son. Lauder formed and funded a recruiting band, actively encouraging young men to enlist. He gave speeches on the virtues of military service and, although too old to fight in the trenches of the First World War, Lauder sang there, accompanied by a small fiveoctave piano designed for that express purpose. After visiting his son's grave, the emotional climax of his French tour, Lauder returned to Britain. He met with the Minister of Pensions to discuss plans for a charity project, the 'Harry Lauder Million-Pound Fund for Maimed Men, Scottish Soldiers and Sailors'; he performed concerts and gave speeches throughout Britain, Canada, and the United States to raise money for the project (Ibid., 96).

It is estimated that over 12,000 troops were recruited through Lauder's efforts and, as a result, he was made a Knight of the British Empire in 1919 (Durndell, 2013). Winston Churchill found that Lauder 'by his inspiring songs and valiant life, rendered measureless service to the Scottish race and to the British Empire' (Churchill, 2005:530). Thus, betwixt his British patriotism, his Scottish iconography, and his Protestant faith, Lauder was the antithesis of the Irish-Catholic rebel; that one of his most lasting legacies in the Scottish conscious is a warped, sectarian version of his 1910 pantomime song seems profoundly paradoxical. To those of a strongly loyalist or unionist persuasion this juxtaposition must only heighten its offensiveness.

\section{Chorus of Roamin' in the Gloamin'}

Roamin' in the Gloamin' with a shamrock in my hand.

Roamin' in the Gloamin' with Saint Patrick's Fenian Band, And when the music stops, fuck King Billy and John Knox, Oh it's good to be a Roman Catholic. ${ }^{42}$

\footnotetext{
${ }^{42}$ When the song is performed, the verses are usually omitted in favour of the shorter, and more rousing, chorus. However, as McKerrell writes of 'The Famine Song', 'the chorus carries the implied meaning of the whole song as a musical synecdoche in abbreviated form' (McKerrell 2012:4).
} 
The chorus derides John Knox, leader of the Protestant Reformation in Scotland, who founded the Church of Scotland in 1560 and 'King Billy', known formally as William III of England and II of Scotland, who took an oath to uphold the 'Protestant reformed religion established by law' (Edwards, 1999:150). However the most bitter language is reserved for the verses, which feature lines such as 'fuck your Queen', while the Orange Order, an exclusively Protestant fraternal organisation that host contentious parades across Scotland and Northern Ireland, are referred to as 'Huns banging drums' and 'big hairy cunts' whose wives smell of 'pish and shite'. ${ }^{43}$ These figures are discussed in opposition to Roman Catholics, establishing a dichotomy between the two. In so doing, it further diminishes the claim that 'Hun' merely denotes a Rangers supporter, as discussed earlier, and emphasises the term's anti-Protestant and sectarian meaning.

\section{Music as a weapon}

It should be noted that there has been considerable opposition to the singing of 'Roamin' in the Gloamin', from within Celtic's support, not least from Celtic's ultras the 'Green Brigade'; ${ }^{44}$ that the song has largely disappeared from football stadiums; and that this happened before the introduction of the 2012 Offensive Behaviour at Football and Threatening Communications (Scotland) Act. Yet while attending the Wolfe Tones' $50^{\text {th }}$ anniversary concert in Glasgow's Barrowlands, on 22 November 2014, I heard the song

\footnotetext{
43 A version of the song has been uploaded onto YouTube by 'Doonthegallowgate': https://www.youtube.com/watch?v=7a7 8fgkDbw The Gallowgate is an area in the East End of Glasgow with strong Irish-Catholic and republican ties. It is home to the main republican organisation in Scotland Cairde $\mathrm{Na}$ hEireann ('Friends of Ireland'); various Irish bars, such as The Emerald Isle, The Hoops Bar, and Bar 67; Celtic shops, such as 'Tim Land' (Tim being a term denoting a Celtic fan); and, most significantly, the Gallowgate houses the stadium of Celtic Football Club. The Gallowgate is also the home of Glasgow's Barrowland Ballrooms, where the Wolfe Tones recorded their $25^{\text {th }}$ anniversary concert and where they perform each year.

44 'Ultras' are 'particularly passionate, emotional, committed and - above all - very active fans who are fascinated by a south European culture of spurring on their team and have made it their job to organise a better, traditional atmosphere in the football stadiums in order to be able to support "their" team creatively and to the best of their ability. This Southern European culture includes not only visual support . . . but also acoustic support by means of drums or songs and chants led by megaphone/microphone' (Pilz and Wölki -Schumacher, 2010:5).
} 
performed - with gusto - by groups of men on two separate occasions and there are those who feel strongly about singing the song and keeping it within the tradition. The following comments were taken from the football forum TalkCeltic.net whilst lurking; they refer to fans' feelings about 'Roamin in the Gloamin' and date back to a thread from March 2008: ${ }^{45}$

'Hate this song religious triumphalism at its fucking best ${ }^{\text {'4 }}$

'Love this song Religious triumphalism and its fucking great ${ }^{47}$

'Celts have a Catholic heritage and they are proud of it, I'm also a religious Catholic and I see no reason not to sing that song cos it only shows our Irish and accordingly Catholic history and roots. that's all about it and I can't understand why you argue so much about that. Anyone who hates Catholic songs or who isn't proud of Celtic's Catholic and Irish heritage should fuck off and join the Huns! all in all I'm at one with Óglaigh na hÉireann, ${ }^{48}$ AndyMc I can’t understand you and hope you are a true Celtic fan, 49

'Same here',50

'i'm a fenian, I've always been a fenian, always will be a fenian...I'll die a fenian...I've sang this song since I was wee...love it!!!!!!!!!!!!!!!!!!we sang it through all the shite we had to wade through growing up, as a testament to our unwavering belief in our faith and heritage, 51

Such comments illustrate the tension within groups of Celtic fans, and by extension, within the Irish-Catholic diaspora more generally, as to how their Irishness, their Catholicism and their support for Celtic should be celebrated - through music - in Scotland. Scotsman's

\footnotetext{
${ }^{45}$ All comments here and in subsequent Internet discussions are reproduced as typed by their authors.

${ }^{46}$ Comment posted by 'AndyMc1888' in the forum TalkCeltic.net, 24 March 2008 at 12.37am.

${ }^{47}$ Comment posted by 'Ghod' in the forum TalkCeltic.net, 24 March 2008 at 12.40am. This member's online signature included pictures of the ten Irish republican prisoners that died on hunger strike in 1981, including Joe McDonnell, under the banner 'Icons of Resistance'.

${ }^{48}$ The Irish phrase Óglaigh na hÉireann translates, roughly, as 'Soldiers of Ireland' and has been used to refer to various groups in Ireland, including the 1913 Irish Volunteers, the Irish Republican Army, and later paramilitary groups such as the Provisional IRA, the Continuity IRA, and the Real IRA. The phrase is the Gaelic name for 'Defence Forces Ireland', the Republic of Ireland's combined army, navy and air force, yet it is also used by dissident republicans still active in Ireland.

${ }^{49}$ Comment posted by 'Scotsman' in the forum TalkCeltic.net, 24 March 2008 at 11.07am.

${ }^{50}$ Comment posted by 'Shaunhai192' in the forum TalkCeltic.net, 24 March 2008 at $1.29 \mathrm{pm}$.

${ }^{51}$ Comment posted by ' 'padros' in the forum TalkCeltic.net, 20 September 2008 at 8.24am.
} 
conflation of Irish and Catholic is an unfortunate syllogism, which compounds the binarisms that often perpetuate sectarian behaviour. More sinisterly, his stating that 'Anyone who hates Catholic songs or who isn't proud of Celtic's Catholic and Irish heritage should fuck off and join the Huns!' and 'AndyMc I can't understand you and hope you're a true Celtic fan', are emblematic of Bourdieu's doxa (1977), whereby a community that feels threatened by others, who affect its reputation, values, or beliefs, tends to protect itself by producing this defensive discourse for orthodoxy.

A more recent thread, again from TalkCeltic.net, forwards similar arguments to those outlined above. However, it presents us with a clearer example of music being deployed as a weapon:

At the end of the day, wether you agree with it or not... It doesn't make one difference to me. I'll be singing it on Sunday and singing italong with another few choice songs as soon as I hear the Hello Hello, Big Jock Knew and The famine Song. Fuck King Billy, John Knox and all the DOBS ${ }^{52}$ giving OUR ENTIRE SUPPORT the same kind of abuse as each other, wether we be Catholic Protestand, Atheist, Muslim etc... 53

Tony Cliffton's insistence that he will sing 'Roamin in the Gloamin', once he hears Rangers fans singing three of Rangers' most anti-Catholic songs is a clear illustration of music's use as a weapon and the power of rebel songs to offend the opposing side. It shows that fans are aware of rebel songs' power, that they relish it, and that they are calculating in how they deploy such music. Such use of music as a weapon is in keeping with models discussed in the wider literature, particularly those theories espoused by Pettan 1998; Cusick 2006 and 2008; Johnson and Cloonan 2008; Goodman 2010; and in O'Connell and Castelo-Branco 2010.

\footnotetext{
${ }^{52}$ DOBS is an abbreviation of 'Dirty Orange Bastards'.

${ }^{53}$ Comment posted by 'Tony Clifton' in the forum TalkCeltic.net, 18 February 2011 at $6.25 \mathrm{pm}$.
} 
It could be argued that this negative manifestation of Catholicism has its positive counterpart, wherein Celtic fans sing Catholic hymns, such as the ever-popular 'Walk With Me Oh My Lord', during games. This could be viewed as an expression of fans' Catholic faith and a tangible, as well as vocal, representation of the club's origins and history. Alternatively, it could be viewed as another example of music's use as a weapon and an illustration that no songs are sacred enough not to be deployed in the denigration of the opposition. Celtic fans' embracing Catholicism could also be read as a means to distance themselves from 'Protestant' Rangers, exaggerating the difference between themselves and their biggest rivals. ${ }^{54}$ This diametrical opposition is evinced through the teams' grafting their difference onto various dichotomies: Catholic/Protestant; Irish/British; nationalist/unionist; republican/loyalist; colonised/coloniser; Constitutive Other/Hegemonic Majority. The tactic serves to heighten tensions and rivalries, even if only superficially, and is common practice within fan culture. ${ }^{55}$ Such 'hegemonic fandom' is characterised by 'spiteful aggression; an appetite for anger and pique; and petty or cultivated hostilities and grudges, typically directed with special venom at one particular level' (Davis 2013:115). In the Scottish context, Davis uses the narrower term of 'football sectarianism', wherein, as above, fans step into identities to polarise, and be polarised by, the opposing side. Despite its not being heartfelt, Davis employs a Kantian universalism to argue that because it 'entails the absence of due respect for the human worth of its victims . . to treat the individual members of at least one group as ends-in-themselves', football sectarianism is 'morally impermissible' (Ibid.,119).

\footnotetext{
${ }^{54}$ For an in-depth discussion of this polarisation by fans, and examples from Panathinaikos and Olympiakos football fans in Greece, see Theodoropoulou 2007.

${ }^{55}$ One European example is the rivalry between Cyprus' APOEL and Omonoia football clubs. Formed in 1948, Omonoia was created when several Communist APOEL players split from the club to create a new team in Nicosia. APOEL fans often use the Greek flag, symbolising their right-wing Hellenism, while Omonoia employ left-wing symbols, such as the hammer and sickle. Although both teams' supporters are predominantly GreekCypriot, APOEL fans use songs to deride Omonoia as 'Turks', while Omonoia sing songs celebrating Turkish victories over Greece to antagonise their rivals.
} 


\section{Conclusion}

In the closing line of his essay, 'Irish Music and Song', the Wolfe Tones' Brian Warfield concludes: 'In the face of bigotry, racism and sectarianism, song and music is a way to challenge these destructive social and cultural forces: so the cry is "let the people sing, their stories and their songs" (Warfield, 2006:186). Yet whether by fault or design, Warfield's deployment of 'Let The People Sing' ${ }^{56}$ as a means to tackle sectarianism through praxis is deeply problematic and displays an ignorance of his own music's political power and the negative sectarian message it connotes for some, outwith the band's fan base. As the growing corpus on music and conflict illustrates, the use of music and songs can be deeply problematic and, rather than challenging destructive social and cultural forces, can serve to compound and perpetuate them; it is the very charge levelled at the Wolfe Tones and the reason much of their music is now banned from public space in Scotland.

The battle against sectarianism has become something of a cause célèbre in Scotland, with successive governments - of various political stripes-committing themselves to tackling the problem through public consultations, changes in the law, and millions of pounds invested in equality programmes. Yet unlike sexism or racism, the country lacks consensus on what constitutes 'sectarianism'. This article has argued that the sectarianism of Irish rebel songs is often contextual and highly contested. Extreme examples of rebel songs, such as 'Roamin in the Gloamin' are overtly sectarian, while more innocuous ballads can become sectarian through lyrical 'add-ins', which inflect the meaning of key songs. Ireland's connection to Scotland, through those who settled there and who went on to form and shape the country's biggest football team, is still reflected in the songs that are sung and those used to offend Celtic's opposition-most notably Rangers FC. However, when there is no explicit guidance on what can and cannot be sung, and no definition as to why such songs are

\footnotetext{
${ }^{56}$ The Wolfe Tones, 'Let The People Sing', A Sense of Freedom. Triskel Records, TRL1012. 1983.
} 
offensive, debates over rebel songs and their use and misuse in Scottish society seem set to continue for some time.

\section{Bibliography}

Adamson, I. 1994. 'The Ulster-Scottish Connection', in Scotland and Ulster, ed. Ian S. Wood. Edinburgh: Mercat, pp.1-21.

Anderson, B. 1991. Imagined Communities: Reflections on the Origin and Spread of Nationalism. London: Verso.

Barthes, R. 1977. Image, Music, Text. Translated by S. Heath. London: Fontana 1977.

BBC. 2012. 'NI's dissident groups to unite under IRA banner', BBC News Northern Ireland, 27 July 2012. Accessed 14 August 2014. http://www.bbc.co.uk/news/uk-northernireland-19009272

Bourdieu, P. 1977. Outline of a Theory of Practice. Translated by Richard Nice. Cambridge: Cambridge University Press.

Boyle, C. 1995. 'The Celtic Sod', Rosses Celtic Supporters Club. Accessed 14 May 2015. http://www.rossescsc.com/TheCelticSod.htm

Boyle, M. 2002. 'Edifying the Rebellious Gael: Uses of memories of Ireland's troubled past among the West of Scotland's Irish Catholic diaspora', in Celtic Geographies: Old Culture, New Times, ed. David C. Harvey, Rhys Jones, Neil McInroy and Christine Milligan. London: Routledge, pp. 173-191.

Bradley, J. M. 1995. Ethnic and Religious Identity in Modern Scotland: Culture, Politics and Football. Aldershot: Avebury Ashgate Publishing.

2004. 'Orangeism in Scotland: Unionism, politics, identity, and football', Eire Ireland, 39/1\&2, pp. 237-261.

2006. 'Sport and the contestation of ethnic identity: Football and Irishness in Scotland', Journal of Ethnic and Migration Studies, 32/7, pp. 1189-1208.

2009. Bronwen Walter, Mary J. Hickman and Sarah Morgan. 'Irish Identities, History, Public Silence and the Celtic Singing Tradition', in Celtic Minded 3: Essays on Religion, Politics, Society, Identity ... and Football, ed. J.M. Bradley. Glendaruel: Argyll Publishing, pp. 193-212.

Bruce, S., T. Glendinning, I. Paterson and M. Rosie. 2004. Sectarianism in Scotland. Edinburgh: Edinburgh University Press.

Burke. M. 2004. 'The Case for Brother Walfrid', in Celtic Minded Essays on Religion, Politics, Society, Identity ... and Football, ed. J.M. Bradley. Glendaruel: Argyll Publishing, pp. 100-105. 
Carrell, S. 2011, 20 April. 'Neil Lennon and two prominent Celtic fans in parcel bomb campaign'. The Guardian. Accessed 26 August 2014.

http://www.theguardian.com/football/2011/apr/20/neil-lennon-targeted-parcel-bomb

Churchill, C. 2011, 28 February. 'Police call for ban on Old Firm clashes'. Herald Scotland. Accessed 26 August 2014. http://www.heraldscotland.com/news/crime-courts/policecall-for-a-ban-on-old-firm-clashes-1.1087524

Churchill, W. S. 2005. The Second World War, Volume 3: The Grand Alliance. London: Penguin.

Cochrane, A. 2013, 12 April. 'Sheriff makes mincemeat of ill-considered law-making'. The Telegraph. Accessed 5 January 2015.

http://www.telegraph.co.uk/news/uknews/scotland/9991384/Sheriff-makes-

mincemeat-of-ill-considered-law-making.html

Cooper, D. 2010. The Musical Traditions of Northern Ireland and its Diaspora. Farnham: Ashgate.

Curtis, L. 1985. Nothing But The Same Old Story: The Roots of Anti-Irish Racism. London: Information of Ireland.

Cusick, S. 2006. 'Music as Torture/Music as a Weapon', Transcultural Music Review, 10. .2008. "“You Are In a Place That is Out of This World...": Music in the Detention Camps of the "Global War on Terror", Journal for the Society for American Music, $2 / 1,1-26$.

Dahlhaus, C. 1980. 'Nationalism and Music', in Between Romanticism and Modernism: Four Studies in the Music of the Later Nineteenth Century. Translated by M. Whittall. Berkeley: University of California Press, pp.79-102.

Davies. A. 2013. "They Sing That Song”: Football and Sectarianism in Glasgow during the 1920s and 1930s', in Bigotry, Football and Scotland, ed. J. Flint and J. Kelly. Edinburgh: Edinburgh University Press, pp. 50-64.

Davis, P. 2013. 'Hegemonic Fandom and the Red Herring of Sectarianism', in Bigotry, Football and Scotland, ed. John Flint and John Kelly. Edinburgh: Edinburgh University Press, pp. 115-129.

Devine, T.M. (ed.) 2000. Scotland's Shame? Bigotry and Sectarianism in Modern Scotland. Edinburgh: Mainstream Publishing.

Doonthegallowgate. 2008. 'Roamin' in the Gloamin'’. YouTube. Accessed August 272014. http://www.youtube.com/watch?v=7a7_8fgkDbw

Durndell, H. 2013. 'Sir Harry Lauder: 1870-1950'. Special Collections Library, University of Glasgow. Accessed 26 August 2014. http://www.gla.ac.uk/services/specialcollections/collectionsa$\mathrm{z} /$ scottishtheatrearchive/stacollections/sirharrylauder/ 
Early, D. 2014, 27 November. 'The Greatest threat to Delaney is John Delaney himself'. Irish Times. Accessed 4 January 2015. http://www.irishtimes.com/sport/soccer/thegreatest-threat-to-delaney-is-john-delaney-himself-1.2017995

Edwards, R. D. 1999. The Faithful Tribe: An Intimate Portrayal of the Loyal Institutions. London: HarperCollins.

Evans, E. J. 2001. The Forging of the Modern State: Early Industrial Britain 1783-1870. $3^{\text {rd }}$ ed. Harlow: Longman.

Fay, M. T., M. Morrissey and M. Smyth. 1998. Mapping Troubles-Related Deaths in Northern Ireland 1969-1998. Londonderry: INCORE.

Findlay, J. 2011. 'Offensive Behaviour at Football and Threatening Communications (Scotland) Bill'. The Scottish Parliament, Justice Committee, $6^{\text {th }}$ Meeting 2011, Session 4. Official Report. Tuesday September 6 2011. Accessed August 262014. http://www.scottish.parliament.uk/parliamentarybusiness/28862.aspx?r=6437\&mode= pdf

Finn, G.P.T. 2000. 'Scottish Myopia and Global Prejudices', in Football Culture: Local contests, global visions, ed. G.P.T. Finn and R. Giulanotti. London; Portland: Frank Cass Publishers, pp. 54-99.

Flint J. and J. Kelly (ed.) 2013. Bigotry, Football and Scotland. Edinburgh: Edinburgh University Press.

Frith, S. 1996. 'Music and Identity', in Questions of Cultural Identity, ed. S. Hall and P. du Gay, 108-127. London: Sage, pp. 108-127.

Gallagher. T. 1987. Glasgow - The Uneasy Peace: Religious Tension in Modern Scotland. Manchester: Manchester University Press.

Gallagher, T. 1991. 'The Catholic Irish in Scotland: in Search of Identity', in Irish Immigrants and Scottish Society in the Nineteenth and Twentieth Centuries, ed. T.M. Devine. Edinburgh: John Donald, pp. 19-43.

Goodall, K., P. Hopkins, S. McKerrell, J. Markey, S. Millar, J. Richardson, M. Richardson, 2015. 'Community Experiences of Sectarianism', Scottish Government Social Research.

Goodall, K., S. McKerrell, J. Markey, S. Millar, M. Richardson. 2015. 'Sectarianism in Scotland: A "West of Scotland" Problem, a Patchwork or a Cobweb?' Scottish Affairs, 24/3, pp. 288-307.

Goodman, S. 2010. Sonic Warfare: Sound, Affect, and the Ecology of Fear. Cambridge, Massachusetts: MIT Press.

Gow, J. D.C. 2013. 'Political Sectarianism Is Still Sectarianism!' The Rangers Standard. Accessed 26 August 2014. http://www.therangersstandard.co.uk/index.php/articles/rfc-politics/239-politicalsectarianism-is-still-sectarianism 
Goulding A. and B. Cavanagh. 2013. 'Charges reported under the Offensive Behaviour at Football and Threatening Communications (Scotland) Act (2012) in 2012-13'. Scottish Government Social Research, Justice Analytical Services.

Grahame, C. 2011. 'Offensive Behaviour at Football and Threatening Communications (Scotland) Bill'. The Scottish Parliament, Justice Committee, $6^{\text {th }}$ Meeting 2011, Session 4. Official Report. Tuesday September 13 2011. Accessed 26 August 2014. http://www.scottish.parliament.uk/parliamentarybusiness/28862.aspx?r=6439\&mode= pdf

Hamilton, T. 2011, 21 April 21. 'Cardinal Keith O'Brien sent a live bullet in the post'. Daily Record. Accessed 26 August 2014. http://www.dailyrecord.co.uk/news/scottishnews/cardinal-keith-obrien-sent-live-1100866

Handley, J.E. 1945. The Irish in Scotland: 1798-1845. $2^{\text {nd }}$ ed. Cork: Cork University Press.

Higgins, G. I. and J. D. Brewer. 2003. 'The Roots of Sectarianism in Northern Ireland', in Researching The Troubles: Social Science Perspectives on the Northern Ireland Conflict, ed. O. Hargie and D. Dickson. Edinburgh: Mainstream Publishing, pp. 107121.

Hinchliffe, S., A. Marcinkiewicz, J, Curtice and R. Ormston. 2015. 'Scottish Social Attitudes Survey 2014: Public Attitudes to Sectarianism in Scotland', Scottish Government Social Research.

Irving, G. 1968. Great Scot: The Life Story of Sir Harry Lauder, Legendary Laird of the Music Hall. London: Leslie Frewin.

Johnson, B. and M. Cloonan. 2008. Dark Side of the Tune: Popular Music and Violence. Aldershot: Ashgate.

Kelly, E. 2003. 'Challenging Sectarianism in Scotland: The Prism of Racism', Scottish Affairs, 42, pp. 32-56.

Kelly, J. 2011. “'Sectarianism” in Scottish Football: Critical Reflections on the Dominant Discourse and Press Commentary', International Review for the Sociology of Sport, 46/4, pp.418-435.

Kenneally, G. 2011. Let The People Sing: The Wolfe Tones Story. Kenneally Films. DVD.

Kenny, P. 2002, February. The Late Late Show. Television broadcast by Radió Teilifís Éireann (RTÉ).

Larkin, C. 31 July, 2013. 'Wolfe Tones'. Encyclopedia of Popular Music, $4^{\text {th }}$ edition. Oxford Music Online. Oxford University Press. Web. Accessed 26 August 2014. http://www.oxfordmusiconline.com/subscriber/article/epm/30775

Lauder, H. 1928. Roamin' In The Gloamin'. London: Hutchinson.O'Connell, J. M. and S. El-Shawan Castelo-Branco (ed.). 2010. Music and Conflict. Urbana: University of Illinois Press.

O'Toole, F. 2002, 12 January. 'Why the end of the Wolfe Tones is music to my ears'. The Irish Times. Accessed 26 August 2014. http://www.irishtimes.com/news/why-theend-of-the-wolfe-tones-is-music-to-my-ears-1.1046483 
McDonald, C. 2011, 7 April 7. 'Builder arrested in Scotland in hunt for killer of Omagh cop Ronan Kerr'. Daily Record. Accessed 26 August 2014.

http://www.dailyrecord.co.uk/news/scottish-news/builder-arrested-in-scotland-inhunt-for-killer-1099641

McEvoy, K. 2001. Paramilitary imprisonment in Northern Ireland: Resistance, management and release. Oxford: Oxford University Press.

McFarland, E. 1990. Protestants First: Orangeism in Nineteenth Century Scotland. Edinburgh: Edinburgh University Press.

McKerrell, S. 2012. 'Hearing Sectarianism: Understanding Scottish Sectarianism as Song', Critical Discourse Studies, 9/4, pp. 1-12. 2015. 'Social Distance and the Multimodal Construction of the Other in Sectarian Song', Social Semiotics, 25/5, pp.614-632.

Marshall, W. S. 1996. 'The Billy Boys': A Concise History of Orangeism in Scotland. Edinburgh: Mercat Press.

Millar, S. R. 2015. 'Musically Consonant, Socially Dissonant: Orange Parades and Catholic Interpretation in West-Central Scotland', Music \& Politics, 9/1, pp.1-23.

Moynihan, M. 2011. 'The Vice Guide to Belfast - Part 4'. Vice. Accessed 26 August 2014. $\mathrm{http}: / /$ www.vice.com/en_uk/vice-news/the-vice-guide-to-belfast-4

Muller, S. 2001. 'Exploring the Aesthetics of Reconciliation: Rugby and the South African National Anthem', South African Journal of Musicology, 21, pp. 19-38.

NFO Social Research. 2003. 'Sectarianism in Glasgow - Final Report'. Edinburgh.

Pettan, S. 1998. 'Music, Politics, and War in Croatia in the 1990s: An Introduction', in Music, Politics and War: Views From Croatia, ed. S. Pettan. Zagreb: Institute of Ethnology and Folklore Research, pp. 9-27.

Pilz G. A. and F. Wölki-Schumacher. 2010, 18 January. 'Overview of the Ultra culture phenomenon of the Europe member states in 2009'. Accessed 26 August 2014. http://www.coe.int/T/dg4/Sport/Source/T-RV/TRV_2010_03_EN_background_doc_Prof_PILZ.pdf

Rose, G. 2012, 25 March. 'Fans fear that guidelines will "sterilise" match culture'. Scotland On Sunday. Accessed 26 August 2014. http://www.scotsman.com/scotland-onsunday-2-7506/politics/fans-anger-at-anti-sectarian-guidelines-that-will-sterilisematch-culture-1-2194917

Rosie, M. 2004. The Sectarian Myth in Scotland: Of Bitter Memory and Bigotry. Basingstoke: Palgrave Macmillan.

Scott, D. 2013. 'Renewed call for Bigotry Rehab Scheme'. Nil By Mouth. Accessed 26 August 2014. http://nilbymouth.org/2013/campaigners-renew-call-for-bigotry-rehabscheme/

Scottish Government. 2011. 'Offensive Behaviour at Football and Threatening Communications (Scotland) Bill, Policy Memorandum'. Accessed 12 May 2015 
Skeide, J.M.L. 2010. 'Sashes and Rosaries: Scottish Sectarianism and the Old Firm'. Unpublished Masters thesis, University of Bergen.

Smyth, J.J. 2000. Labour in Glasgow, 1896-1936: Socialism, Suffrage, Sectarianism. East Linton, East Lothian: Tuckwell Press.

Stokes, M. 1994. 'Introduction: Ethnicity, Identity and Music', in Ethnicity, Identity and Music, ed. M. Stokes. Oxford: Berg, pp. 1-27.

Taruskin, R. 2010. The Danger of Music and Other Anti-Utopian Essays. London: University of California Press.

Taylor, P. 1997. Provos: The IRA and Sinn Fein. London: Bloomsbury.

Theodoropoulou, V. 2007. 'The Anti-Fan Within the Fan', in Fandom: Identities and Communities in a Mediated World, ed. J. Gray. New York: New York University Press, pp. 316-327.

TNS-BMRB. 2011. 'Sectarianism Poll: Prepared For Scottish Government'. Edinburgh.

Waiton, S. 2012. Snobs' Law: Criminalising Football Fans in an Age of Intolerance. Dundee: Take a Liberty Scotland.

Warfield, B. 2006. 'Irish Music and Song', in Celtic Minded 2: Essays on Celtic Football Culture and Identity, ed. J. M. Bradley. Glendaruel: Argyll Publishing. . 2011, 16 November. 'Professional Letter'. The Wolfe Tones: Irish Folk Legends. Accessed 26 August 2014. http://www.wolfetonesofficialsite.com/statement.htm

Warfield, R. 2012. 'Huge Success'. The Wolf Tones: Irish Folk Legends. Accessed August 26 2014. http://www.wolfetonesofficialsite.com/menu.htm

Watt, C. 2011, 18 May 18. 'Lennon hits out a "Celtic minority's chants"' Herald Scotland. Accessed 26 August 2014. http://www.heraldscotland.com/news/home-news/lennonhits-out-at-celtic-minority-s-chants. 13723917

Wood, I. 1994. 'Thin Red Line? Scottish Soldiers in the Troubles', in Scotland and Ulster, ed. Ian S. Wood. Edinburgh: Mercat, pp.150-171.

\section{Discography}

Harry Lauder. 'Roamin' In The Gloamin', Roamin' In The Gloamin', Pegasus, B000067OUN. 2008.

The Wolfe Tones. 'The Boys of the Old Brigade', 'Till Ireland a Nation. Dolphin Records, DOL1006. 1974

. 'The Celtic People', Child of Destiny. Dolphin Records, B0069CLPVQ. 2012.

. 'Celtic Symphony', Celtic Symphony. Celtic Collections, CCCD023. 2006.

. 'The Foggy Dew', The Foggy Dew. Fontana Records, TL5244. 1965. 
. 'Joe McDonnell', A Sense of Freedom. BMG, B000000E0M. 1983.

_ 'Let The People Sing', A Sense of Freedom. Triskel Records, TRL1012. 1983.

. 'The Merry Ploughboy', The Teddy Bear's Head. Fontana Records, TE17491. 1967. 